\title{
Model of nursing management of a Child with Crouzon SYNDROME aCCORDING to the InTERnational Classification fOr Nursing Practice ${ }^{\circledR}$
}

Agata Cieniawa ${ }^{A, B, C, D}$

Department of Nephrology, The University Hospital, Krakow, Poland

Authors' contribution:

A. Study design/planning • B. Data collection/entry • C. Data analysis/statistics $\bullet$ D. Data

interpretation $\bullet$ E. Preparation of manuscript $\bullet$ F. Literature analysis/search $\bullet$ G. Funds collection

\author{
Address for correspondence: \\ Agata Cieniawa \\ Department of Nephrology \\ The University Hospital \\ Krakow, Poland \\ e-mail: agataciesielczyk@onet.pl \\ SUBMITTED: 14.04 .2020 \\ ACCEPTED: 15.06 .2020 \\ DOl: https://doi.org/10.5114/ppiel.2020.98772
}

\begin{abstract}
Introduction: Crouzon syndrome is a genetic disease causing a set of congenital cranial anomalies. The disorder results from a mutation in the FGFR2 gene. Abnormalities arising from the defect in the gene lead to severe cranial deformities due to the premature fusion of one or more craniofacial sutures.

Aim of the study: To present nursing and care of a patient with Crouzon syndrome using the International Classification for Nursing Practice (ICNP ${ }^{\oplus}$ ) terminology.

Material and methods: The study was based on the research method of a case study using a range of case study tools and techniques, such as interview, observation, and analysis of medical records of a two-year-old boy suffering from Crouzon syndrome. The identification of 12 nursing diagnoses along with nursing interventions was performed on the basis of the ICNP ${ }^{\oplus}$.

Results and conclusions: Crouzon syndrome is a rare genetic disease that causes severe skull deformities and numerous disorders, as a result of which the treatment process is long and difficult for children and their carers. Patients require individual care tailored to their needs. The scope of nursing interventions included monitoring according to ICNP ${ }^{\oplus}$ : the child's status, signs of worsening pain, identifying deficits in child's development, and providing informational and emotional support to child carers. In-depth observation allowed for early diagnosis and elimination of constipation, gas exchange disorders through the tracheotomy tube, and skin integrity disorders in the area of gastrostomy and tracheostomy. Thanks to the ICNP ${ }^{\circledast}$ reference terminology, it was possible to formulate 12 diagnoses and appropriate nursing interventions to care for children with Crouzon syndrome.
\end{abstract}

Key words: Crouzon syndrome, child, nursing management.

\section{INTRODUCTION}

Crouzon syndrome, also referred to as craniofacial dysostosis (Latin: dysostosis craniofacialis), is a rare genetic disease. It was first described by the French neurologist Octave Crouzon in 1912. The disorder is estimated to occur in 1 per 250,000 live births, and the prevalence is the same in children of both sexes. Craniofacial dysostosis is a genetic disorder resulting from a mutation in the gene encoding FGFR2 [1]. Abnormalities arising from the defect in the gene lead to severe cranial deformities due to the premature fusion of one or more craniofacial sutures. The process of craniosynostosis occurs at the age of one to three years. During this period, the child's brain increases in volume by approximately 2.5 to 3 times [2]. In the majority of reported cases, permanent premature closure of cranial sutures is a cause of acute intracranial hypertension syndrome. The disease does not lead to the premature closure of the anterior and posterior fontanelles [1, 3].

The effects of the process include cranial deformity, elevated intracranial pressure, shallow orbits and ocular proptosis, malocclusion, cleft palate, and psychomotor retardation. Children with Crouzon syndrome have characteristic facial features: the upper lip is shortened, the middle part of the face is underdeveloped, and the infraorbital area is flattened. Another common feature in the facial appearance of Crouzon patients is a parrot-beaked nose [4-7].

In many cases, the process of ossification begins during foetal development, which is the main cause of permanent head defects in newborns [8]. Crouzon syndrome cannot be detected by standard ultrasound scanning or prenatal screening during pregnancy. However, it is possible to diagnose the disease 
in an unborn child in reference centres where genetic sonography is performed $[9,10]$. Crouzon syndrome has a very low prevalence, so knowledge of the disorder among medical professionals is rather poor compared to other conditions which are diagnosed far more frequently after birth [11].

The cranial shape in patients diagnosed with this pathology varies depending on multiple factors in cluding the following:

- degree of stenosis,

- age of suture closure,

- sequence of craniofacial bone fusion,

- progression of stenosis [2].

The heads of children with craniofacial dysostosis assume different shapes depending on which sutures are affected:

- short and broad (brachycephaly), as a result of premature fusion of the coronal suture;

- long and narrow (scaphocephaly), as a result of premature fusion of the sagittal suture;

- triangular (trigonocephaly), as a result of premature fusion of the metopic suture;

- asymmetric (plagiocephaly), as a result of premature fusion of the coronal suture or the lambdoid suture [4].

The International Classification for Nursing Practice $\left(\right.$ ICNP $\left.^{\oplus}\right)$ has been developed by the International Council of Nurses as a system offering globally unified nursing terminology. ICNP ${ }^{\circledR}$ is a universal standardised language which ensures successful communication in the nursing process.

A major benefit of the classification can be demonstrated, for example, in the introduction of care that is more targeted towards patients. A care plan developed on the basis of ICNP ${ }^{\circledR}$ terminology eliminates the duplication of patient information, shows the effects of nursing activities, focuses on what the nurse should do (rather than document what already has been done), and highlights specific interventions undertaken as part of patient care as well as their results $[12,13]$.

\section{AIM OF THE STUDY}

To present nursing and care of patients with Crouzon syndrome using the ICNP ${ }^{\circledR}$ terminology.

\section{MATERIAL AND METHODS}

The study was based on the case study research method using a range of case study tools and techniques, such as interview, observation, and analysis of medical records of a two-year-old boy suffering from Crouzon syndrome. The identification of 12 nursing diagnoses along with nursing interventions was performed on the basis of the International Classification for Nursing Practice. ICNP® terms derived from the axis were used in the work: subject (DC - Diagnosis, F - Focus); location ( $L$ - Location); funds ( $M$ - Means); client (C - Client) (version from 2018).

\section{DESCRIPTION OF THE PATIENT'S HEALTH STATUS}

A child with Crouzon syndrome, born by caesarean section at 37 weeks' gestation, of pregnancy complicated by oligohydramnios. The boy had presented with visible head deformity since birth. During the first dozen or so months of life, in the course of frequent hospitalisations, and after a wide range of diagnostic examinations and tests the following findings were made: long, narrow cranium with a bone defect in the occipital region, narrow face, ocular proptosis and red eyes. Because of congenital laryngeal incompetence and obstruction of posterior nasal apertures on the right, characteristic audible stridor was present during respiration. Other manifestations include secondary hydrocephalus, high-arched palate, atresia of the external auditory meatus in the left ear, and narrowing of the auditory meatus in the right ear. The boy has a funnel-shaped chest and low-set ears. During the first weeks of life, the boy was diagnosed with gastroesophageal reflux disease and gastroesophageal disorders. Persistent vomiting prevented normal weight gain, leading to malnutrition and general body weakness. Because the boy failed to reach a body weight of $5 \mathrm{~kg}$ at the age of six months, a decision was made to insert a gastrostomy tube. The child gradually began to gain weight. The boy received formula foods (FSMP), with occasional constipation. During a subsequent hospitalisation, because of deteriorating general condition and progressive shortness of breath due to total upper respiratory tract obstruction, a tracheostomy was done for respiratory support. The boy underwent cranioplasty due to craniocerebral dysostosis, and a subgaleal drain was placed on the left in order to reduce secondary hydrocephalus. The surgical procedures were uncomplicated. During the study, the boy was two years old. He stayed then at the Social Welfare Home for Children and Adolescents with Intellectual Disabilities run by nuns from the Congregation of Our Lady of Mercy. The child was placed in the centre temporarily, at the parents' request, after spending several months in hospital. This decision was caused by the parents' stress about their ability to provide the boy with sufficient care. The parents regularly visit their son in the care centre. They are actively involved in the child's care and engaged in the process of treatment and rehabilitation. During the observation period, the boy periodically experienced constipation.

The accumulation of large amounts of thick secretions in the lower bronchial tree made it difficult 
for the boy to have normal, unobstructed gas exchange. Another problem that arose was ulceration of the right eye caused by ocular proptosis due to shallow eye sockets. The boy has compromised immunity and is highly susceptible to lower respiratory infections. Large head and impaired muscle tension cause difficulties with maintaining balance, which increases the risk of falling. During the first year of life, the child's development was severely disturbed. Because of his bad overall condition, the boy spent most of his time in hospitals, where his activity was significantly reduced on account of his poor general status. After stabilising the boy's condition, a general rehabilitation regime was initiated. The degree of psychomotor impairment was significant. At two years old, the boy's gross motor skills were equivalent to those of a typically developing 12-month-old child. Skin irritation is often observed in the area of the tracheostomy and gastronomy tubes. Despite the dietary guidelines used, the boy was still underweight. The BMI value is 12.8 .

\section{PLAN FOR THE NURSING MANAGEMENT OF A CHILD WITH CROUZON SYNDROME}

\section{Diagnosis I}

Impaired gas exchange [10001177] + deadline on the axis, F: discharge [10017635] + deadline on the axis, L: airways [10002100]

ICNP ${ }^{\circledR}$ interventions:

1. Continuous surveillance [10005093].

2. Arranging transport of device [10030493] + term from $M$ axis: humidifier [10009228].

3. Monitoring vital signs [10032113].

4. Monitoring blood oxygen saturation using pulse oximeter [10032047].

5. Respiratory tract suction [10044895].

6. Assessing tissue perfusion [10030775].

7. Positioning patient [10014761].

Outcome: Effective gas exchange [10027993].

\section{Diagnosis II}

Suspicion [10022805] + term from axis, DC: impaired hearing [10022544]

ICNP ${ }^{\circledR}$ interventions:

1. Screening hearing [10032703].

2. Teaching adaptation techniques for sensory deficit [10024641] + date on the M axis: therapy [10019628] + date with axis, C: guardian [10003958]. Outcome: Impaired hearing [10022544].

\section{Diagnosis III}

Risk for constipation [10015053]

${ }^{\prime C N P}{ }^{\circledR}$ interventions:

1. Prevention of constipation [10046454].

2. Monitoring fluid intake [10035303].
3. Managing defecation [10041427].

Outcome: Impaired bowel movement [10012652].

\section{Diagnosis IV}

Risk for impaired skin integrity [10015237] + term

from the L axis: tracheostomy [10019933]

$\mathrm{ICNP}^{\oplus}$ interventions:

1. Assessing skin integrity [10033922].

2. Teaching about tracheostomy care [10044888] + term from axis, C: guardian [10003958].

3. Skin care [10032477] + date on the F axis: water [10020957], date on the $M$ axis: soap [10018358], date on the $M$ axis: ointment.

4. Assessing self-care of skin [10030747] term from axis, C: guardian [10003958].

5. Promoting hygiene [10032742] + date with axis, C: child [10004266].

Outcome: correct skin integrity [10028501].

\section{Diagnosis $\mathrm{V}$}

Risk for infection [10015133] + date with axis,

F: respiratory system [10016970] ICNP ${ }^{\circledast}$ interventions:

1. Evaluating signs and symptoms of infection [10044182].

2. Assessing susceptibility to infection [10002821].

3. Monitoring signs and symptoms of infection [10012203].

4. Use of aseptic technique [10041784].

5. Preventing infection [10036916].

6. Teaching about risk reduction technique [10038804] + date with axis, C: guardians [10003958].

Outcome: infection [10023032].

\section{Diagnosis VI}

\section{Continuity of care problem [10029759]}

${ }^{\prime C N P}{ }^{\circledR}$ interventions:

1. Discharge planning [10006016] + date on the L axis: hospital [10009114].

2. Teaching caregiver [10033086].

3. Assessing caregiver knowledge [10033876].

4. Supporting caregiver [10024570].

5. Ensuring continuity of care [10006966].

6. Assessing caregiver stress [10024222].

Outcome: Ensuring continuity of care [10006966].

\section{Diagnosis VII}

Risk for fall [10015122]

ICNP $^{\oplus}$ interventions:

1. Assisting in walking [10038986].

2. Teaching about fall prevention [10040253] + deadline on the axis, C: guardians [10003958].

3. Assessing risk for falls [100235520].

4. Teaching family about fall prevention [10040269]. Outcome: Fall [10029405]. 


\section{Diagnosis VIII}

Impaired psychomotor activity [10025087]

ICNP ${ }^{\circledast}$ interventions:

1. Promoting physical mobility [10037379].

2. Monitoring activity tolerance [10036622].

3. Increasing activity tolerance [10024884].

4. Promoting exercise [10040834] + term from axis, C: child [10004266].

5. Reinforcing muscle or joint exercise technique [10036512].

6. Teaching about child safety [10037160]. Outcome: Impaired psychomotor activity [10025087].

\section{Diagnosis IX}

Pain caused by a wound [10021243]

ICNP ${ }^{\oplus}$ interventions:

1. Monitoring pain [10038929].

2. Nurse-controlled pain management [10039798].

3. Monitoring response to treatment [10032109].

4. Administering pain medication [10023084].

5. Introduction of analgesic guidelines [10009872].

6. Teaching about pain [10039115] + term from axis, C: guardian [10003958].

Outcome: No pain [10029012].

\section{Diagnosis $\mathrm{X}$}

\section{Guardian's stress [10027773]}

ICNP ${ }^{\circledR}$ interventions:

1. Supporting the guardian [10024570].

2. Assessing caregiver stress [10027794].

3. Supporting psychological status [10019161].

4. Ensuring privacy [10026399].

5. Facilitating communication of feelings [10026616]. Outcome: decreasing caregiver stress [10027794].

\section{Diagnosis XI}

\section{Underweight [10014075]}

ICNP ${ }^{\circledR}$ interventions:

1. Assessing nutrition status [10030660].

2. Monitoring food intake [10036614].

3. Monitoring fluid intake [10035303].

4. Enteral nutrition management [10031795]. Outcome: readiness for proper nutritional status [10001513].

\section{Diagnosis XII}

Self-care deficit [10023410] + term from axis,

\section{C: child [10004266]}

ICNP ${ }^{\oplus}$ interventions:

1. Assessing needs [10033368] + term from axis, C: child [10004266].

2. Care plan order [10013765].

3. Assisting the caregiver [10030809].

4. Assessing compliance with recommendations [10024185].

Outcome: Positive attitude towards care [10022275].

\section{CONCLUSIONS}

Crouzon syndrome is a very rare genetic disorder. Multiple anomalies and their effects accompanying the condition present a great challenge to healthcare professionals. The patient's somatic and psychosocial problems were described by the following ICNP ${ }^{\oplus}$ diagnoses: impaired gas exchange, risk of impaired hearing, risk of constipation, risk of impaired skin integrity, risk of respiratory infection, continuity of care problem, risk of fall, impaired psychomotor activity, eye pain, caregiver stress, underweight, and self-care deficit. The diagnoses presented mainly concern the child, and in one diagnosis they are directed to parents, which refers to the concept of child care based on Child-Centred Care (CCC), which takes into account the entire person of the child, not just the disease, and is associated with the general experience of the child and family [14].

The scope of interventions included providing information and emotional support as well as educational assistance to the parents and nuns taking care of the child with Crouzon syndrome. Due to the rarity of using Crouzon syndrome, currently there are no consulting services in the field of procedure assessment, care should be taken on experienced nurses professions, general knowledge in solving the current but also very complex health services of the child, therapeutics, and nursing. Careful patient observation allowed early detection and elimination of constipation, disturbances of gas exchange through the tracheotomy tube, monitoring of pain, and disorders of skin integrity around the gastrostomy and tracheostomy sites. The boy is currently receiving general rehabilitation, which has a favourable effect on his development. ICNP ${ }^{\circledast}$ terminology was found to be an effective tool for the formulation of diagnoses and nursing interventions in the management of a child with Crouzon syndrome.

\section{Disclosure}

The author declares no conflict of interest.

\section{References}

1. Gizik M, Kowalska E, Larysz D, Wolański W. Komputerowe metody wspomagania leczenia kraniosynstozy. Modelowanie Inżynierskie 2011; 41: 437-444.

2. Białkowska-Głowacka J, Jannas A, Osica P, Stelmach R. Zespół Crouzona - opis przypadku. Dental Forum 2015; 43: 107-110.

3. Larysz D. Specjalistyczne koło przyjaciół dzieci z dyskraniami. www.kraniostenoza.pl/index.php/leczoper (10.03.2016).

4. Larysz D. Ocena wyników leczenia izolowanych kraniosynostoz u dzieci z uwzględnieniem aspektów klinicznych biomechanicznych oraz neurorozwojowych. BEL Studio, Warszawa 2013.

5. Jagielak M, Perkowski K, Piekarczyk J, et al. Zespół Crouzona na podstawie piśmiennictwa i obserwacji własnych. Czas Stomatologii 2006; 5: 349-360. 
6. Gizik M, Larysz D, Wolański W. Inżynierskie wspomaganie endoskopowych zabiegów neurochirurgicznych. Modelowanie Inżynierskie 2011; 41: 429-436.

7. Gizik-Zroska B, Gizik M, Tejszerska D, Wolański W. Komputerowe wspomaganie leczenia zabiegów korekcji trigoncefalii u dzieci. Modelowanie Inżynierskie 2009; 38: 51-56.

8. Banaszkiewicz A, Radzikowski A, Sieniewicz E. Rozwój dziecka i metody jego oceny. In: Pediatria i podręcznik dla studentów pielęgniarstwa. Banaszkiewicz A, Radzikowski A (Eds.). MediPage, Warszawa 2008; 1-18.

9. Cepuch G, Perek M. Schorzenia układu krwiotwórczego. In: Modele pielęgnowania dziecka przewlekle chorego. Cepuch G, Krzeczowska B, Perek M, Twarduś K (Eds.). Wydawnictwo Lekarskie PZWL, Warszawa 2011; 47-69.

10. Cepuch G. Schorzenia układu kostno-stawowego i tkanki łącznej. In: Modele pielęgnowania dziecka przewlekle chorego. Cepuch G, Krzeczowska B, Perek M, Twarduś K (Eds.). Wydawnictwo Lekarskie PZWL, Warszawa 2011; 97-117.

11. Twarduś K, Perek M. Dziecko niepełnosprawne ruchowo i intelektualnie. In: Modele pielęgnowania dziecka przewlekle chorego. Cepuch G, Krzeczowska B, Perek M, Twarduś K (Eds.). Wydawnictwo Lekarskie PZWL, Warszawa 2011; 293-324.

12. Kilańska D. Terminologia referencyjna i jej znacznie dla praktyki. In: Kilańska D, Grabowska H, Gaworska-Krzemińska A (Eds.). E-zdrowie. Wprowadzenie do informatyki w pielęgniarstwie. Wydawnictwo Lekarskie PZWL, Warszawa 2018; 345-365.

13. International Council of Nurses. Pillars \& Programmes. Professional Practice. eHealth. International Classification for Nursing Practice (ICNP®). ICNP Browser. http://www.icn.ch/ ICNP-Browser-NEW.html (13.01.2018).

14. Feeg VD, Shields L. Family centered or child centered care? Strengths and challenges to theoretical and practice implementation. J Pediatr Nurs 2018; 43: A7-A8. 